\title{
A KUTATÁS KALAND
}

Az augusztus végi napsütésben, a bársonyos meleg füvön önfeledten hempergődzött a két kócos, kétéves forma dédunoka. Megéreztek valamit a helyzet komolyságából, mert csendben maradtak, és időnként a közelben csoportosuló fölnőttekre pillantottak. A csoportban álló rokonok és idegen, komoly ismeretlenek búcsúztató beszédeket hallgattak, majd virágokat halmoztak egy sírra. Ök is csendben voltak, vagy halkan beszéltek egymással. Beck Mihály vegyészprofeszszor hamvait fogadta vissza a késő nyári anyaföld 2017. augusztus 31-én, a Fiumei úti Sírkert akadémiai parcellájában.

Beck Mihály Tibor magyar kémikus, tudománytörténész, egyetemi tanár, a Magyar Tudományos Akadémia rendes tagja 88 éves korában, egy hónappal azt követően hunyt el, hogy megjelent Silberer Vera vele készült beszélgetéseiről összeállított írása. Ezek a „válogatott írások” a Lexica Kiadó megbízásából, a Magyar Tudományos Akadémia támogatásával készültek mint a magyar tudósok életmüvét bemutató sorozat hetedik kötete. A kiadó e sorozattal arra vállalkozott, hogy bemutatja néhány sikeres professzor munkásságát és élettörténetét. A kiadó megbízását ez alkalommal az indokolta, hogy a köztiszteletben álló emeritus professzor 2016-ban kapta meg a legmagasabb magyar tudományos elismerést, az Akadémiai Aranyérmet.

Dr. Silberer Vera Akadémiai Újságírói díjas, okleveles vegyész, fizikus, tudományos újságíró és szerkesztő ez alkalommal Beck Mihállyal beszélgetett. A gazdagon illusztrált interjúkötet nemcsak a hatvan év vegyész-tudósi életmüvet mutatja be, hanem Beck Mihály gyermekkorába, baráti kapcsolataiba és magánéletébe is bepillantást enged. Különösen érdekes (a szintén vegyész) társával, Ébrey Piroskával való hatvan évig tartó házasságának története, ami a szegedi egyetemen kezdődött. Az olvasó megismerheti Beck professzor szőregi gyermekéveit és szegedi ifjúságát. A Szegedi iskolák és szegedi évek fejezet a politikától és ideológiai vitáktól sem mentes tudományos pályára állás éveit, az első szakmai sikerek idejét ismerteti. Beck professzor mindig határozott és őszinte volt ideológiai és világnézeti kérdésekben. Silberer Vera így idézi Beck Mihályt: „A közösségi jellemvonásokat elismerem, de amikor egyetlen emberről beszélünk, ezeket figyelmen kívül kell hagynunk. Beck Mihály, született Szőregen 1929-ben. Az ő megítélése szempontjából nem az a fontos, hogy zsidó volt, hogy rossz tanuló volt, hanem az, hogy milyen vegyész lett belőle. Mindehhez hozzáteszem, hogy egyértelmúen magyar hazafinak (de nem »hazaffy«-nak) tartottam és tartom magam." 
A könyv harmadik fejezetében a Beck család debreceni éveit tudósi pályájának teljes kibontakozását, professzorrá válását és nemzetközi kapcsolatainak megalapozását ismerhetjük meg. Itt, Debrecenben vált iskolateremtő professzorrá, a Kossuth Lajos Tudományegyetem rektorává, az akadémia rendes tagjává, az MTA Kémiai Tudományok Osztálya elnökévé majd sok-sok nemzetközi szervezet tisztségviselőjévé. Szakterülete a már szegedi éveiben megkezdett téma folytatása, a koordinációs kémia maradt. Az egyetemen a Fizikai kémiai tanszék vezetője volt, igen népszerü előadó és önálló kutatások szervezője. Utóbbiról idéz Silberer Vera: „Minden kutató nagy felfedezésekről álmodik, de csak keveseknek adatik meg az álom beteljesedése. Két lehetőség nyílik a csalódottság elkerülésére. Az egyik a saját eredmények önmagát becsapó túlértékelése, a másik lehetőség annak megértése, hogy a jó kutatás valójában ismeretlen területekre vezető kaland, mely az új dolgok megismerése mellett lehetővé teszi a megismerési alapelvek és a kutatás pszichológiai törvényszerüségeinek a felfedezését függetlenül az eredmények valódi értékétől."

Beck Mihály több mint négyszáz cikket írt, egyik legismertebb szabadalma pedig az elemi jód kinyerése természetes ásványvizekből.

Külön fejezetben olvashatunk utazásairól, melyek közül legfontosabbak az amerikai vendégoktatói tartózkodások voltak, amikor találkozhatott ifjúkori legjobb barátjával, a szintén vegyész, USA-ban élő Berg Árpáddal. Vele tudott igazán hahotázni a régi csínyek emlékén, egészen Árpád haláláig, ami nem sokkal előzte meg saját búcsúját az élettől.

Ahogy Görög Sándor (az első akadémikus Beck-tanítvány) a könyv bevezetöjében említi, Beck Mihály kémikusi tevékenysége hamar túllépte a kémia határait. Általános tudománypolitikai, majd tudományetikai kérdésekkel is magas szinten foglalkozott (például elnöke volt az MTA Etikai Bizottságának).

A riporter-író külön fejezetben foglalkozik Beck professzor áltudományt bíráló és leleplező munkásságával. Ez az a terület, ahol igen népszerü előadóvá és vitatkozó partnerré válva sok ezren ismerték meg Beck Mihály nevét. Népszerü, hiteles, „,igazi tudósként” ismerték meg a tévénézők is.

A kötet hetedik fejezete a professzor tudománytörténészi és numizmatikusi tevékenységét mutatja be. Ezek az idősödő Beck Mihály legismertebb, legsikeresebb szakterületei. Than Károlyról (1833-1908) a modern magyar kémiai oktatás megteremtőjéről nagyszámú publikációt és sikeres könyvet írt. A kedvtelésből kezdett érem- (és érme-) gyüjtést is komolyan vette, és egyes szakterületek - például a konferenciai emlékérmek története - kiváló ismerője lett.

A kötet válogatást is közöl Beck Mihály több száz írásából: A tudományos gondolkodás kihivásai; Javaslat a Tudományetikai kódex alapelveire; Szerek és szertelenségek; A Magyar Orvosok és Természetvizsgálók Vándorgyüléseinek története; Különleges alakú és anyagú érmék. 
Zárófejezetként Beck Mihály gazdag tudományos életrajzát is olvashatjuk Silberer Vera értékes könyvében, amelynek megjelenését a Magyar Tudományos Akadémia támogatta, elkészültét pedig Liptay György segítette. A kötet azokra a visszaemlékezésekre és dokumentumokra is támaszkodik, amelyeket Tömpe Péter rögzített 2015-2016-ban.

(Silberer Vera: A kutatás kaland. Életút-beszélgetések Beck Mihállyal. [Magyar Tudósok VII.] Budapest: Lexica Kiadó, 2017, 196 o. http://real.mtak.hu/58918/)

Tömpe Péter

$\mathrm{PhD}$, címzetes egyetemi docens, Budapesti Múszaki és Gazdaságtudományi Egyetem Szerves Kémia és Technológia Tanszék 